ISSN 1392-3196 / e-ISSN 2335-8947

Zemdirbyste-Agriculture, vol. 101, No. 2 (2014), p. 153-160

DOI 10.13080/z-a.2014.101.020

\title{
Agrobiological potential of some soil crucifers of Lithuania's spontaneous flora
}

\author{
Nijolė MARŠALKIENE $\dot{E}^{1}$, Algirdas SLIESARAVIČIUS ${ }^{1}$, Asta RAMAŠKEVIČIENÉ ${ }^{1}$, \\ Liuda ŽILĖNAITÉ ${ }^{1}$, Gintautas Juozas ŠVIRMICKAS ${ }^{2}$ \\ ${ }^{1}$ Aleksandras Stulginskis University \\ Studentų 11, Akademija, Kaunas distr., Lithuania \\ E-mail: nijole.marsalkiene@asu.lt \\ ${ }^{2}$ Institute of Animal Science of Veterinary Academy, Lithuanian University of Health Sciences \\ R. Žebenkos 12, Baisogala, Radviliškis distr., Lithuania
}

\begin{abstract}
A total of 56 seed samples of five spontaneus Brassicaceae species - flixweed (Descurainia sophia L.), wallflower mustard (Erysimum cheiranthoides L.), fanweed (Thlaspi arvense L.), sea rocket (Cakile baltica Jord. ex Pobed.) and garlic mustard (Alliaria petiolata (M. Bieb.)) were collected in different regions of Lithuania. The samples were sown in autumn (2008-2009) and spring (2009-2010) in the fields of Experimental Station of Lithuanian University of Agriculture on a Calc(ar)i-Epihypogleyic Luvisol ( $L V g-p-w-c c)$.

Phenological observations and assessment of productivity parameters were performed. All the investigated autumn-sown species, except for T. arvense, produced higher stems and surpassed spring-sown plants in productivity parameters. Meanwhile, for $T$. arvense the weather conditions had greater influence than sowing time. The most stable parameters for the study period were the amount of oil in seeds $(V=6.3-11.3)$ and the number of silicles per inflorescence $(V=20.7-$ 43.2). The most unstable parameters were the number of inflorescences $(V=30.93-94.4)$ and seed yield per plant $(V=$ 16.5-135.0). D. sophia $(6.4 \pm 0.9 \mathrm{~g})$ exhibited the highest single plant productivity and stability of features. Among the studied species $E$. cheiranthoides distinguished itself by the highest ( $37.8 \pm 2.6 \%$ DM (dry mass) and the most stable $(V=6.9)$ oil content in the seeds.
\end{abstract}

Key words: Alliaria petiolata, Brassicaceae, Cakile baltica, Descurainia sophia, Erysimum cheiranthoides, oil, productivity, seed yield, silicle, Thlaspi arvense.

\section{Introduction}

Environmental concerns are driving industry to develop viable alternative fuels from renewable resources (Piazza, Foglia, 2001). During the last decades, demand for vegetable oils as food, non-food and biofuel has grown significantly (Carr, 1985). Crop development and species diversity are important aspects of the emerging global bioeconomy, as is maximizing crop value through total crop utilization (Taylor et al., 2010). Characterization and use of crop biodiversity is essential to provide the range of alternative crop varieties needed to meet the changing needs of the World (Carr, 1985). The potential of wild germplasm to provide novel sources of economic traits in oil plant breeding programs has increased in the last 15-20 years with the development of biotechnology and its utilization as a breeding tool (Warwick et al., 1999).

Brassicaceae family plays an important role in the global agriculture and horticulture and contributes both to the economies and health of populations around the World. Brassicaceae crops are among the oldest cultivated crops. Written records of man cultivating Brassicaceae crops date back to $1500 \mathrm{BC}$, and archaeological evidence of the crops importance dates back to 5000 BC (Raymer, 2002). Oilseed crops of the crucifers are widely adapted and are of particular importance to countries in the northern latitudes (Downey, 1971). Crucifer species are characterised by extensive morphological diversity and ability to adapt to a wide range of habitats and growing environments. Brassicaceae are the most interesting botanical family for producing erucic acid, due to the large number of suitable species and varieties, providing on their own the whole amount of erucic acid needed worldwide (Zanetti et al., 2012). Recently, there has been strong pressure from agricultural and industrial lobbies to develop very high-erucic-acid rapeseed varieties adapted to non-food use (Taylor et al., 2010), firstly, to absorb crop surpluses and reduce "set aside" development and secondly, to reduce the dependence on finite fossil oils (Norton, Harris, 1983). It is also important to look for alternative feed stocks, new species of oilseed crops, for the production of biodiesel and vegetable oil aiming to avoid cross pollination of high-erucic-acid and oil rapeseed varieties and to use less fertile soils, lesser fertilizers and pesticides.

In Lithuania, there are 87 species and 40 genera of crucifers and most of them are elements of wild flora (Jankevičienè, 1971). Such species have not been 
sufficiently researched and assessed because the main focus of attention has been cultural oil plants. At the Lithuanian University of Agriculture (LUA, currently - Aleksandras Stulginskis University) the study of wild crucifers was started in 2008. The aim of research was to study Brassicaceae family species as potential producers of oil.

Descurainia sophia. Since D. sophia is considered to be an extremely important plant in Iran, India, China, and other countries and an important weed in the US and Europe, numerous studies have been carried out concerning its chemical compositions, physiology, and methods for controlling its propagation (Aghaabasi, Baghizadeh, 2012). However, studies on introducing this species for practical use were limited (Peng et al., 1997). The oil content in D. sophia seeds ranges from $23.2 \%$ to 37.6\% (Peng et al., 1997; Goffman et al., 1999).

Erysimum cheiranthoides is one of the well known weeds of the mustard family and has probably been making a nuisance of itself to European farmers since the very beginning of agriculture. According to the literature data, the seed oil is applied in the industries of soap (Giontar, Godin, 2004; 2005). The seed contains $20.7-40.2 \%$ of oil (Dolya et al., 1973; Goffman et al., 1999).

Thalaspi arvense is an annual or winter annual species that has an ancient association with agriculture and humans reaching back to the Stone Age (Carr, 1985; 1993; Warwick et al., 2002). T. arvense was rated as having potential as a new industrial crop (Carr, 1993). T. arvense oil appears to be an acceptable feedstock for biodiesel production (Moser et al., 2008; 2009). The seed of $T$. arvense contains 26.0-36.5\% of oil (Carr, 1993; Goffman et al., 1999).

Cakile baltica. The halophyte $C$. baltica grows in Lithuania on coastal protective dunes, which have not only the economic and ecological aspects, but also recreational (Olšauskas, Olšauskaitė-Urbonienè, 2002). The actual seed yield (and the yield potential) of halophytes remains largely unknown since their domestication is still limited despite the fact that these plants tolerate extremely harsh conditions (Gandour et al., 2012). Foreign authors have reported that $C$. baltica seeds contain 40.3-44.0\% oil (Miller et al., 1965; Dolya et al., 1973).

Alliaria petiolata is a biennial (and sometimes perennial) species native to Europe (Meekins, McCarthy, 2000). A. petiolata has a wide tolerance of environmental conditions for growth and reproduction (Cavers et al., 1979; Byers, Quinn, 1998), oil content in seeds amounts to 22.0-26.2\% (Miller et al., 1965; Goffman et al., 1999).

For interspecific and intraspecific biochemical composition 116 seeds samples of listed above species were analysed in 2008. The highest oil content was determined in seeds (dry mass) of D. sophia (32.2\%) and E. cheiranthoides (30.6\%). In seed oil of D. sophia, E. cheiranthoides and C.baltica unsaturated (oleic, linoleic, linolenic) oils prevailed. The greatest amount of erucic acid was determined in seed oil of $A$. petiolata (49.3\%) and T. arvense (35.6\%) (Maršalkienè et al., 2009).
The task of the trial was to research agrobiological features of Descurainia sophia, Erysimum cheiranthoides, Thlaspi arvense, Cakile baltica and Alliaria petiolata.

\section{Materials and methods}

Seeds of 10 accessions of flixweed (Descurainia sophia L.), 17 samples of wallflower mustard (Erysimum cheiranthoides L.), 22 accessions of fanweed (Thlaspi arvense L.), 5 samples of sea rocket (Cakile baltica Jord. ex Pobed.) and 2 accessions of garlic mustard (Alliaria petiolata (M. Bieb.)) were collected all over Lithuanian territory. Plant seeds were collected within the period of ripening from June to September. Seeds of T. arvense were the earliest to ripen and collected from the middle of June till September. Seeds of $A$. petiolata and C. baltica were collected in August. Seeds of E. cheiranthoides ripened and were collected in August and September.

Experimental site and time. In the autumn of 2008 (September 5), 2009 (September 10) and spring 2009 (May 8), 2010 (May 5) seed samples were sown and grown at the Experimental Station of Lithuanian University of Agriculture, Middle Lithuania, on soil - on medium loam Calc(ar)i-Epihypogleyic Luvisol ( LVg-p-wcc), neutral: $\mathrm{pH}-\mathrm{KCl} 7.1-7.3$, containing $238-315 \mathrm{mg} \mathrm{kg}^{-1}$ of mobile phosphorus $\left(\mathrm{P}_{2} \mathrm{O}_{5}\right), 154-172 \mathrm{mg} \mathrm{kg}^{-1}$ of mobile potassium $\left(\mathrm{K}_{2} \mathrm{O}\right), 1.70-2.45 \%$ of humus. In August, the field was ploughed; the seedbed was prepared by a cultivator and a harrow.

Experimental design. The experiment consisted of three replicates of a randomized design. The size of each sample plot was $1 \mathrm{~m}^{2}$, space between plots was $0.5 \mathrm{~m}$. Seeds were hand-planted and hand-thinned at the eight-leaf stage to achieve final plant stands of 50 plants $\mathrm{m}^{-2}$ of $C$. baltica and 100 plants $\mathrm{m}^{-2}$ of other species. Weed incidence was assessed after full crop emergence. The plots were hand-harvested at full maturity. No fertilization was applied. In the spring of 2009 and 2010, at two-leaf stage, seedlings were damaged by flea beetle (Chaetocnema), especially those of the C. baltica. A. petiolata were least attractive to flea beetle. For flea beetle control we used Fastac ${ }^{\circledR} 50$ EC (a.i. alfacipermetrin $100 \mathrm{~g} \mathrm{l}^{-1}$ ) $-0.201 \mathrm{ha}^{-1}$. Plant assessment was based on measurements of stem height, number of inflorescences (branches for $T$. arvense) and silicles, seed yield of one plant (for C. baltica - yield of fruits). Phenological observation and biochemical analyses of seed oil content were performed too.

Oil determination in seeds. Seed oil content and composition were determined at the Institute of Animal Science of Veterinary Academy, Lithuanian University of Health Sciences. Representative average samples were used. They were ground so that at least $90 \%$ of the sample passed a sieve of $0.300 \mathrm{~mm}$ mesh size. Total fat was determined according to Gerhard Application 3.4.1. The sample weight was determined by aiming to achieve a target of extracting $0.5-1.5 \mathrm{~g}$ fat; so up to $5 \mathrm{~g}$ sample was weighed into the beaker with $1 \mathrm{mg}$ precision. The protein of the sample was digested by $100 \mathrm{ml}$ boiling hydrochloric acid $\left(4 \mathrm{~mol} \mathrm{l}^{-1}\right)$ to break the lipo-protein 
and lipo-cellulose bonds. The liquid was quickly brought to boiling and simmered with reduced heating capacity for about $1 \mathrm{~h}$. At the end of the hydrolysis the digestion mixture was diluted to the double amount with cold water and was then immediately filtered through pleated filter, which was moistened with water. The beaker and the condenser were rinsed at least three times with hot $\left(40^{\circ} \mathrm{C}\right)$ water. The filter also was rinsed till the indicator paper became a neutral reaction to the water. The filter with sample was then placed on a watch glass and dried for about $1.5 \mathrm{~h}$ at $102 \pm 2{ }^{\circ} \mathrm{C}$ in a drying oven.

After cooling, the filter was placed in an extraction thimble and covered with cotton wool. Any remaining fat traces on the watch glass were taken up with some cotton wool, damp with extraction agent, and put inside the extraction thimble as well. After adding petrol ether $\left(40-60^{\circ} \mathrm{C}\right)$ the sample was extracted in the "Soxterm Multistat/SX PC" ("Gerhardt GmbBH and Co. KG", Germany) automatically using hand-picked program. Duration of hot extraction was $40 \mathrm{~min}$. Total time of fat extraction was $2 \mathrm{~h}$ and $5 \mathrm{~min}$. After the program was run, the extraction beakers were dried in the drying chamber in an upright position for $75 \mathrm{~min}$ at $103 \pm$ $2{ }^{\circ} \mathrm{C}$. Extraction beakers were weighted with a precision of $1 \mathrm{mg}$ after cooling in desiccators. The fat content was calculated from the difference between the weight of the extraction beaker at the end and the start of the analysis. Each sample was analysed at least twice. The deviation between double determinations was not more than $0.1 \%$.

Meteorological conditions. The Lithuanian climate lies between maritime and continental, with wet winters and moderate summers. Winter temperatures are usually below freezing. The weather in August 2008 was warm and rainy, September was cooler and dryer. In 2009, the period for seed emergence was semifavourable, the shortage of precipitation occurred in the $2^{\text {nd }}$ ten-day period of May, but the weather was warm. Warm weather and abundant precipitation in July and August prolonged flowering and seed ripening period. In 2010, heavy rains occurred during seed emergence. This resulted in soil surface compaction, low germination and weak plant growth. July and August were substantially warmer than usual.

Table 1. Meteorological conditions during crucifers' growing season

Kaunas (Noreikiškès) Meteorological Station, 2008-2010

\begin{tabular}{lcccccccc}
\hline & \multicolumn{3}{c}{ Average air temperature ${ }^{\circ} \mathrm{C}$} & \multicolumn{5}{c}{ Total rainfall mm } \\
\cline { 2 - 9 } & 2008 & 2009 & 2010 & $\begin{array}{c}1974-2006 \\
\text { mean }\end{array}$ & 2008 & 2009 & 2010 & $\begin{array}{c}1974-2006 \\
\text { mean }\end{array}$ \\
\cline { 2 - 9 } January & -3.8 & -3.4 & -10.2 & -3.5 & 74.5 & 72.2 & 20.1 & 42.8 \\
February & -3.0 & -3.4 & -3.9 & -3.3 & 74.5 & 41.6 & 39.0 & 29.6 \\
March & 2.5 & -0.9 & 0.1 & 0.3 & 61.0 & 47.4 & 29.9 & 40.0 \\
April & 8.8 & 8.9 & 7.4 & 6.7 & 32.6 & 8.6 & 58.5 & 38.1 \\
May & 12.2 & 12.7 & 13.7 & 12.6 & 35.6 & 42.0 & 53.8 & 47.2 \\
June & 16.0 & 14.8 & 16.5 & 15.6 & 83.4 & 107.4 & 127.0 & 47.2 \\
July & 19.3 & 18.4 & 21.9 & 17.6 & 44.8 & 83.8 & 101.0 & 83.0 \\
August & 17.7 & 16.9 & 19.7 & 17.1 & 99.0 & 87.5 & - & 73.2 \\
September & 12.2 & 13.8 & 12.0 & 12.2 & 28.2 & 28.3 & 63.3 & 53.8 \\
October & 8.7 & 5.4 & 6.8 & 7.1 & 70.0 & 101.7 & 75.3 & 54.8 \\
November & 3.3 & 3.9 & 1.5 & 1.9 & 30.0 & 75.3 & 48.2 & 48.2 \\
December & 0.3 & -2.5 & -3.3 & -2.0 & 49.0 & 47.3 & 9.5 & 49.5 \\
\hline
\end{tabular}

Statistical data analysis. The data are reported as mean \pm standard deviation of the mean and were examined using analysis of variance ( $A N O V A$ ) procedures. To assess significant differences among the species and between sowing years, $t$-test was used (Čekanavičius, Murauskas, 2000). Data analyses were performed using the software STATISTICA 8.

\section{Results and discussion}

Phenological observation. Autumn-sown seeds of $T$. arvense and $E$. cheiranthoides germinated in autumn (Table 2), while seeds of $C$. baltica and A. petiolata overwintered and germinated in spring. D. sophia by Tavili et al. (2010) could be annual or biannual. D. sophia had good germination in autumn and only two springsown D. sophia samples germinated in 2009 and three - in 2010. This suggests that some ecotypes of $D$. sophia do not need low temperature for breaking seed dormancy.
C. baltica and $A$. petiolata germinated at the latest time. The spring-sown $T$. arvense seed had worse germination in comparison with autumn sown-seed. Poor germination of spring-sown $T$. arvense seeds was marked by Carr (1993) too. E. cheiranthoides had good germination both in spring and autumn. In the spring of 2010 germination rate of plants was negatively affected by cool and wet weather, especially of $T$. arvense. Some of autumnsown $T$. arvense samples were in full flowering by the end of May, while others - by mid-June. T. arvense and D. sophia that had emerged in spring started flowering in the second half of June, while E. cheiranthoides of both sowing dates was in full-flower by the end of June and some samples - by the beginning of July. Seed ripening among E. cheiranthoides accessions, depending on the year and sowing time, differed by 8-17 days (August), D. sophia (end of July - beginning of August) - 9-14, T. arvense (July - beginning of August) - 14-29 days. Such differences of flowering and ripening time could 
be determined by ecological-geographical conditions of accessions' origin. In 2009, warm weather and abundant precipitation in July and August prolonged flowering and seed ripening period. Hot summer and dry August of 2010 shortened plant vegetation. In the first year after sowing $A$. petiolata produced rosettes and flowered in the second (2008 autumn-sown) or the third year (2009 spring-sown). E. cheiranthoides accessions, originated from the Western part of Lithuania, flowered and ripened later like the samples that originated from the Eastern and Southern parts. Proximity to the Baltic sea, cooler summer temperatures, larger amount of moisture, longer vegetation period compared to other regions could be the determining factors for later flowering and ripening of $E$. cheiranthoides accessions from the western part of Lithuania. Origin of other investigated species did not have evident influence on flowering and ripening time. T. arvense showed the shortest life cycle of the investigated species.

Table 2. Phenology of cultivated crucifer species

LUA Experimental Station (Middle Lithuania), 2008-2010

\begin{tabular}{|c|c|c|c|c|c|}
\hline Plant & $\begin{array}{c}\text { Sowing } \\
\text { year }\end{array}$ & Germination & Full flowering & Maturity & $\begin{array}{l}\text { Life cycle } \\
\text { (days) }\end{array}$ \\
\hline \multicolumn{6}{|c|}{ Autumn-sown } \\
\hline \multirow{2}{*}{$\begin{array}{l}\text { Descurainia } \\
\text { sophia }\end{array}$} & 2008 & 24-27 March 2009 & 11-20 June & 28 July-11 August & $139-153$ \\
\hline & 2009 & 20-26 April 2010 & $10-25$ June & 13-23 July & $94-104$ \\
\hline \multirow{2}{*}{$\begin{array}{l}\text { Erysimum } \\
\text { cheiranthoides }\end{array}$} & 2008 & 22-24 September & 8 June-17 July & 11-28 August & $322-339$ \\
\hline & 2009 & 28-30 September & 14 June-25 July & 01-11 August & $304-315$ \\
\hline \multirow{2}{*}{ Thlaspi arvense } & 2008 & 20 September-05 October & 29 May-12 June & 07 July-06 August & $283-318$ \\
\hline & 2009 & 05-22 October & 31 May-15 June & 02-29 July & 269-299 \\
\hline \multirow{2}{*}{ Cakile baltica } & 2008 & 05-12 May 2009 & June 27 & 28 August & 115 \\
\hline & 2009 & 21-25 May 2010 & 29 June-03 July & 25 August & 96 \\
\hline \multirow{2}{*}{ Alliaria petiolata } & 2008 & 24-26 September & 30 May (2010) & 02 July (2010) & 674 \\
\hline & 2009 & 30 September-02 October & - & - & - \\
\hline \multicolumn{6}{|c|}{ Spring-sown } \\
\hline \multirow{2}{*}{$\begin{array}{l}\text { Descurainia } \\
\text { sophia }\end{array}$} & 2009 & 24-25 May & 5-7 July & 22 July-08 August & $90-100$ \\
\hline & 2010 & 22-26 May & 25 June-2 July & 20-29 July & $91-100$ \\
\hline \multirow{2}{*}{$\begin{array}{l}\text { Erysimum } \\
\text { cheiranthoides }\end{array}$} & 2009 & 20-24 May & 29 June-17 July & 11-28 August & $83-100$ \\
\hline & 2010 & 20-26 May & 25 June-2 July & 03-09 August & $79-87$ \\
\hline Thlaspi arvense & 2009 & 17 May-20 June & 05 July-25 July & 29 July-22 August & $72-96$ \\
\hline \multirow{2}{*}{ Cakile baltica } & 2009 & 28 May-05 June & 17 August-17 September & 15-17 September & $110-112$ \\
\hline & 2010 & 10-15 June & 02 August- 02 September & 02 September & 85 \\
\hline Alliaria petiolata & 2009 & 02-05 June & 16 May (2010) & 07 July (2010) & 402 \\
\hline
\end{tabular}

Descurainia sophia. Stem height of autumnsown flixweed (D. sophia) differed between years by $11.2 \mathrm{~cm}$ (Table 3 ), as well as the number of inflorescences varied greatly. In 2010, the particularly favourable year for plant vegetation, D. sophia produced in average 5 times more inflorescences than in 2009. In 2010, some individuals produced to 565 inflorescences. Meanwhile, the number of silicles per inflorescence in both years of this study was similar. Seed yield of single plant in 2010 was 2.4 times higher than in 2009. Seed yield from a single plant of particular samples of 2009 autumn-sown ranged from 6.7 to 10.5 grams, and in 2009 - from 3.6 to $6.7 \mathrm{~g}$. Warm and sufficiently humid weather had a positive impact on oil synthesis; oil content in seeds in 2010 was higher by $3.2 \%$. In favourable 2009 compared with 2010 in spring-sown $D$. sophia the height of stem was by $47 \%$ $(46.5 \mathrm{~cm})$ higher, the number of inflorescences -8.5 times, the number of silicles in single inflorescence -2.5 times, the mass of seeds of a single plant -3.1 times, oil content - by $4 \%$ higher. In 2009 , both spring and autumnsown D. sophia plants, compared with 2010 , increased in height in average by $23 \%(24.1 \mathrm{~cm})(P<0.05)$, produced 8 times more inflorescences $(P<0.05)$, by $15 \%$ higher number of silicles (differences not significant) and 53.5\% $(3.9 \mathrm{~g})$ higher yield $(P<0.05)$. According to the data presented by Chinese authors (Peng et al., 1997), similar amounts of plant seed yield $(6.8-8.4 \mathrm{~g})$ and oil content in seeds (32.2-35.2) were found in autumn-sown $D$. sophia. Data are not available on spring-sown $D$. sophia.

Erysimumcheiranthoides. Duringresearchyears the autumn-sown wallflower mustard (E. cheiranthoides) in comparison to the spring-sown produced higher stems (Table 4) by $11.0 \%$ in 2009 and by $43.3 \%$ in 2010 . The number of inflorescences of the autumn-sown wallflower was twice higher in 2010 and nearly 3 (2.9) times higher in 2009. During the growth period the meteorological conditions particularly influenced the number of inflorescences. Number of inflorescences of the autumnsown E. cheiranthoides in favourable 2009, compared with 2010, was 4 times higher, of the spring-sown E. cheiranthoides - 5.8 times higher. The number of silicles per inflorescence varied much less. The number of inflorescences determined yield differences per plant. Autumn-sown $E$. cheiranthoides produced 2 times more seeds than spring-sown $(P<0.05)$. In 2009, autumnsown $E$. cheiranthoides seed yield was more than twice (2.2) higher in 2010. In spring-sown wallflowers in 2010 a single plant seed yield was extremely low and in the individual samples it was as low as $0.3-1.37 \mathrm{~g}$. The highest seed yield per plant was in 2010 from the most 
Table 3. Morphometric and productivity parameters of flixweed (Descurainia sophia)

LUA Experimental Station (Middle Lithuania), 2008-2010

\begin{tabular}{|c|c|c|c|c|c|c|}
\hline \multirow{2}{*}{ Parameters } & \multicolumn{2}{|c|}{ Autumn-sown, mean \pm SD } & \multicolumn{2}{|c|}{ Spring-sown, mean $\pm \mathrm{SD}$} & \multirow{2}{*}{$t$} & \multirow{2}{*}{$V$} \\
\hline & 2008 & 2009 & 2009 & 2010 & & \\
\hline Stem height $\mathrm{cm}$ & $106.7 \pm 7.4$ & $95.5 \pm 8.7$ & $99.4 \pm 15.5$ & $52.9 \pm 10.7$ & $5.356^{*}$ & 23.2 \\
\hline Number of inflorescences & $171.0 \pm 145.6$ & $23.73 \pm 9.7$ & $113.3 \pm 13.2$ & $13.2 \pm 7.7$ & 0.978 & 90.2 \\
\hline Number of silicles & $45.90 \pm 9.0$ & $49.90 \pm 6.6$ & $63.15 \pm 7.3$ & $24.4 \pm 1.6$ & $2.586^{*}$ & 27.5 \\
\hline Seed weight $g$ & $8.7 \pm 1.4$ & $3.6 \pm 1.12$ & $7.2 \pm 1.5$ & $2.3 \pm 0.4$ & 0.855 & 36.8 \\
\hline Seed oil content $\%$ & $33.8 \pm 2.8$ & $30.6 \pm 2.6$ & $34.4 \pm 5.3$ & $30.35 \pm 2.75$ & -20.23 & 11.3 \\
\hline
\end{tabular}

$\mathrm{SD}$ - standard deviation, $t$ - test value, $V$ - coefficient of variation; ${ }^{*}$ - significant at the 0.05 probability level

Table 4. Morphometric and productivity parameters of wallflower mustard (Erysimum cheiranthoides)

LUA Experimental Station (Middle Lithuania), 2008-2010

\begin{tabular}{lcccccrr}
\hline \multirow{2}{*}{\multicolumn{1}{c}{ Parameters }} & \multicolumn{2}{c}{ Autumn-sown, mean \pm SD } & \multicolumn{2}{c}{ Spring-sown, mean \pm SD } & \multirow{2}{*}{$t$} & \multirow{2}{*}{$V$} \\
\cline { 2 - 5 } & 2008 & 2009 & 2009 & 2010 & & & \\
\hline Stem height cm & $90.0 \pm 14.9$ & $80.8 \pm 10.5$ & $80.1 \pm 13.4$ & $45.8 \pm 9.2$ & $5.212^{*}$ & 28.4 \\
Number of inflorescences & $45.8 \pm 52.7$ & $11.5 \pm 6.1$ & $22.7 \pm 10.1$ & $3.9 \pm 1.5$ & $2.079^{*}$ & 94.4 \\
Number of silicles & $47.7 \pm 6.4$ & $56.2 \pm 6.4$ & $45.1 \pm 8.4$ & $31.7 \pm 10.7$ & $2.586^{*}$ & 33.8 \\
Seed weight g & $6.4 \pm 3.8$ & $2.9 \pm 1.3$ & $3.6 \pm 2.2$ & $0.5 \pm 0.31$ & $5.188^{*}$ & 135.0 \\
Seed oil content \% & $38.4 \pm 2.2$ & $35.7 \pm 2.2$ & $39.9 \pm 5.3$ & $37.1 \pm 2.60$ & -1.300 & 6.9 \\
\hline
\end{tabular}

Explanations under Table 3

distant habitat location in the west of Lithuania (Preila, Klaipeda district) $-13.2 \mathrm{~g}$ and seed weight of single plats was up to $19.2 \mathrm{~g}$. This sample in both years of the study differed by the longest vegetation and latest ripening of seeds. In 2009, E. cheiranthoides, both autumn and spring-sown, compared with 2010, in average increased by $27.1 \%(23.0 \mathrm{~cm})$ in height $(P<0.05)$, produced 4.4 times more inflorescences $(P<0.05), 13.8 \%$ more silicles (differences not significant) and $66.0 \%(3.3 \mathrm{~g})$ higher yield $(P<0.05)$. The oil content in seeds in 2009 was also by $3.5 \%$ higher $(P<0.05)$. Oil content in seeds from the individual samples in this study ranged from $32.2 \%$ to $42.5 \%$. In 2009 oil content of both sowing dates in average was $38.8 \%$, and in $2010-36.3 \%$ (differences are statistically significant). Only one literature source is found about cultivated E. cheiranthoides. Seed mass of spring-sown E. cheiranthoides, found by Central Siberia's researchers, varied from 1.1 to $8.1 \mathrm{~g}$. Seed weight of one plant and the number of inflorescences were found most flexible parameters (Giontar, Godin, 2004; 2005), which agreed with our results.
Thalaspi arvense. During the study years fanweed (T. arvense) productivity was higher in springsown crops than in autumn (Table 5). Autumn-sown plants in 2009 grew by $7.6 \%(3 \mathrm{~cm})$ lower and in average they had $38.8 \%$ less first rank branches and $44 \%$ less second rank branches in comparison with samples of spring-sown T. arvense. However, in 2010, when the year was less favourable for vegetative growth, the result was opposite. Autumn-sown samples produced $12 \%(4.5 \mathrm{~cm})$ higher stem and had more first and second rank branches. However, when compared with 2010 spring-sown plants; autumn-sown plants formed $36 \%$ (8.8 pcs) less silicles of the first rank. The largest weight of seeds was obtained in 2009 from spring-sown T. arvense samples. The seed yield from a single plant of the individual samples ranged from 1.0 to $15.3 \mathrm{~g}$, in 2010 autumn-sown - from 0.9 to $2.3 \mathrm{~g}$. The oil content in T. arvense seeds in 2010 was $1.5 \%$ higher than in 2009. In 2009 autumn and springsown $T$. arvense samples, compared with 2010 , produced the stems of similar height $(p=0.108)$, but produced 2.1 times more of the first rank branches $(P<0.05)$ and 4.5 times more of the second rank branches $(P<0.05)$.

Table 5. Morphometric and productivity parameters of fanweed (Thlaspi arvense)

LUA Experimental Station (Middle Lithuania), 2008-2010

\begin{tabular}{lcccccc}
\hline \multirow{2}{*}{ Parameters } & \multicolumn{2}{c}{ Autumn-sown, mean \pm SD } & \multicolumn{2}{c}{ Spring-sown, mean \pm SD } & \multirow{2}{*}{$t$} & $V$ \\
\cline { 2 - 5 } & 2008 & 2009 & 2009 & 2010 & & \\
\hline Stem height cm & $36.4 \pm 6.3$ & $38.0 \pm 7.9$ & $39.4 \pm 5.2$ & $33.5 \pm 7.5$ & 1.931 & 22.4 \\
$1^{\text {st }}$ rank branches & $7.9 \pm 7.8$ & $5.0 \pm 0.8$ & $12.9 \pm 7.7$ & $4.6 \pm 2.4$ & -1.450 & 82.5 \\
$2^{\text {nd }}$ rank branches & $6.9 \pm 4.8$ & $2.3 \pm 2.1$ & $7.6 \pm 6.8$ & $1.4 \pm 3.4$ & 0.442 & 97.5 \\
$1^{\text {st }}$ rank silicles & $28.5 \pm 7.0$ & $15.7 \pm 4.1$ & $43.2 \pm 7.3$ & $24.5 \pm 16.5$ & $-3.261^{*}$ & 43.2 \\
$2^{\text {nd }}$ rank silicles & $7.9 \pm 5.7$ & $3.1 \pm 6.4$ & $6.2 \pm 3.8$ & $3.1 \pm 3.4$ & 1.282 & 82.3 \\
Seed weight g & $3.9 \pm 3.2$ & $1.5 \pm 0.5$ & $5.4 \pm 3.9$ & $2.9 \pm 1.2$ & -1.574 & 84.3 \\
Seed oil content \% & $28.1 \pm 1.6$ & $25.2 \pm 3.1$ & $26.9 \pm 0.9$ & $25.4 \pm 1.6$ & $2.068^{*}$ & 7.4 \\
\hline
\end{tabular}

Explanations under Table 3 
In 2009, T. arvense produced $38.6 \%$ more first rank silicles $(P<0.05), 57.2 \%$ more second rank silicles $(P<0.05)$ and $66.0 \%(3.3 \mathrm{~g})$ higher yield $(P<0.05)$. The oil content in seeds in 2009 yield was also by $3.5 \%$ higher $(P<0.05)$. Oil content in seeds of individual samples in the study ranged from $32.2 \%$ to $42.5 \%$. In 2009 , the yield of both sowing dates in average was $38.8 \%$, in $2010-36.3 \%$ higher $(P<0.05)$. Hume $(1990)$ reported that in field studies spring - emerging $T$. arvense plants produced $11.0-6.0 \mathrm{~g}$ seeds per plant. In other studies seed yield varied from 119 to $1628 \mathrm{~kg} \mathrm{l} \mathrm{ha}^{-1}$ in different years (Carr, 1993). The field studies showed strong variability of $T$. arvense seed yield and morphological parameters caused by the weather. Sowing time (autumn, spring) had a lesser impact on $T$. arvense productivity (Hume, 1990; Carr, 1993).

Cakile baltica. In 2009, autumn-sown sea rocket $(C$. baltica) produced $4.9 \mathrm{~cm}$ higher bushes than the spring-sown plants of the same year (Table 6). C. baltica also produced 5.6 (23\%) more inflorescences, but a similar number of fruits, as during the harvest time some flowers still blossomed and some fruits did not have enough time to ripen. The oil content was similar. Bushes of 2010 autumn sowing sea rocket grew $3.4 \mathrm{~cm}$ higher than the spring-sown plants of the same year; they produced a similar number of inflorescences and mass of fruits. Comparing performance parameters of the C. baltica of years 2009 and 2010, it is observed that in 2009 plants grew taller and produced more fruits. Favourable weather conditions enabled longer blooming and formation of more inflorescences and fruits. It also significantly impacted the synthesis of oils, in 2009 the oil content in the sea rocket seeds was $19.9 \%$, and in $2010-15.3 \%$. Field studies have not been conducted on C. baltica, but the plant is attractive for scientists as a halophyte and oil plant.

Table 6. Morphometric and productivity parameters of sea rocket (Cakile baltica)

LUA Experimental Station (Middle Lithuania), 2008-2010

\begin{tabular}{lcccccrr}
\hline \multirow{2}{*}{\multicolumn{1}{c}{ Parameters }} & \multicolumn{2}{c}{ Autumn-sown, mean \pm SD } & \multicolumn{2}{c}{ Spring-sown, mean \pm SD } & \multirow{2}{*}{$t$} & $V$ \\
\cline { 2 - 5 } & 2008 & 2009 & 2009 & 2010 & & & \\
\hline Stem height cm & $33.5 \pm 6.4$ & $22.4 \pm 5.2$ & $28.6 \pm 9.2$ & $19.0 \pm 3.4$ & $1.820^{*}$ & 19.8 \\
Number of inflorescences & $24.7 \pm 2.5$ & $6.4 \pm 1.3$ & $19.1 \pm 1.8$ & $5.8 \pm 1.9$ & $2.228^{*}$ & 30.5 \\
Number of fruits & $9.4 \pm 2.4$ & $5.9 \pm 1.9$ & $7.2 \pm 2.0$ & $4.6 \pm 2.4$ & 1.600 & 6.0 \\
Mass of fruit g & $22.1 \pm 3.5$ & $9.2 \pm 3.6$ & $19.7 \pm 4.6$ & $8.4 \pm 2.6$ & $1.633^{*}$ & 26.9 \\
Seed oil content \% & 19.6 & 15.6 & 20.2 & 14.93 & 0.011 & 6.3 \\
\hline
\end{tabular}

Explanations under Table 3

Alliaria petiolata. Both autumn (2008) and spring (2009) sown garlic mustard (A. petiolata) samples produced their seeds only in 2010. Parameters of garlic and mustard of both sowing dates differed insignificantly, except number of inflorescences (Table 7). Samples of autumn-sown $A$. petiolata produced by 3.7 (25\%) more inflorescences than spring-sown, and exceeded seed weight by $25 \%(1.9 \mathrm{~g})$. The oil content was similar. Limited data on similar studies were found about A. petiolata. Many studies were conducted in natural communities investigating garlic mustard as an invasive plant, but not under cultivation (Cavers et al., 1979; Byers, Quinn, 1998).

Table 7. Morphometric and productivity parameters of garlic mustard (Alliaria petiolata)

LUA Experimental Station (Middle Lithuania), 2008-2010

\begin{tabular}{lcccr}
\hline \multirow{2}{*}{ Parameters } & Autumn-sown, mean \pm SD & Spring-sown, mean \pm SD & \multirow{2}{*}{$t$} & \\
\cline { 2 - 3 } & 2008 & 2009 & & \\
\hline Stem height cm & $98.5 \pm 3.7$ & $97.0 \pm 2.8$ & 0.462 & 1.9 \\
Number of inflorescences & $14.8 \pm 5.6$ & $11.1 \pm 5.1$ & $0.018^{*}$ & 30.9 \\
Number of silicles & $14.4 \pm 2.8$ & $15.1 \pm 1.7$ & 0.320 & 20.7 \\
Seed weight g & $7.6 \pm 1.1$ & $5.7 \pm 1.6$ & 0.133 & 16.5 \\
Seed oil content \% & $21.2 \pm 0.7$ & $20.8 \pm 0.5$ & 0.914 & 9.5 \\
\hline
\end{tabular}

Explanations under Table 3

Sharply differing meteorological conditions during the research years revealed the differences and opportunities of growth and productivity of the tested species. Drought stress in summer and heavy rains in spring resulting in soil crusts probably were the main causes of the reduced plant productivity. During the years of this study the majority of plants responded to the favourable growth conditions by producing a higher number of inflorescences. The total number of inflorescences per plant was the most unstable reproductive feature during the experiment. The number of inflorescences of the investigated species between autumn and spring-sown, as well as of different years of growth, differed several times. This is in agreement with the findings of other authors who reported that the number of inflorescences varied greatly among the years (Peng et al., 1997; Giontar, Godin, 2004; 2005). D. sophia produced the largest seed mass per plant (in average $6.4+0.9 \mathrm{~g}$ ) (compared 
to $T$. arvense and A. petiolata, differences in mass are statistically significant). In addition, the quantity of silicles and seed yield were most stable in D. sophia and varied the least. All the investigated autumn sown species, except $T$. arvense, produced higher stems and exceeded the spring-sown plants in productivity parameters. Meanwhile, for T. arvense weather conditions had greater influence than sowing time. The positive effect of autumnsown on morphological and productivity parameters of weedy crucifers, except $T$. arvense, was observed by other authors (Carr, 1993). During the growing season in favourable or improved growing conditions $T$. arvense produced additional second-rank, and in some cases even third-rank inflorescences and silicles, which agreed with results of other authors (Warwick et al., 2002). The number of silicles of $T$. arvense, especially in the second-rank, varied several times more than of other species. T. arvense was also distinguished by the richest phenological diversity and the shortest growing season (of spring sown) among the studied species. The antropopochores T. arvense, D. sophia and E. cheiranthoides, annual or winter annual, were commonly found in ruderal and segetal communities, and could grow in different soils. Great sensitivity of T. arvense can be a problem to its cultivation, meanwhile, during variable meteorological conditions and increasing likelihood of droughts the stability of parameters of $D$. sophia may be advantageous. Halophyte $C$. baltica and biannual A. petiolata are plants of specific habitats; therefore they cannot be directly assessed and compared with three the above mentioned "weed" species. A. petiolata grows mainly in forested communities, in more or less shade, so its yield and formation of inflorescences could have been affected by the particularly hot and sunny summer of 2010 . The relatively low oil content of the seeds may be compensated by particularly high erucic acid content in oil.

\section{Conclusions}

1. Autumn-sown fanweed (Thlaspi arvense) and wallflower mustard (Erysimum cheiranthoides) germinated well in autumn, seeds offlixweed (Descurainia sophia), sea rocket (Cakile baltica) and garlic mustard (Alliaria petiolata) overwintered and germinated in spring. All investigated spring-sown species germinated well, except for D. sophia. Only two samples of $D$. sophia were determined where low temperature for breaking dormancy had less impact compared to others.

2 . The longest life cycle among annual species was recorded for E. cheiranthoides (90-100 days), the shortest for $T$. arvense (72-96 days). The geographical interaction between the western location sites and phenological indicators of the E. cheiranthoides was defined. Biannual $A$. petiolata had the longest life cycle (402 and 674 days).

3. All investigated autumn-sown species, except $T$. arvense, produced higher stems and exceeded the spring sown plants in productivity parameters.

4. The majority of plants responded to the favourable growth conditions by producing a higher number of inflorescences. A total number of inflorescences per plant was the most unstable ( $V=30.93-94.4)$ reproductive feature during the experiment. Most stable indicators for the study period were the quantity of oil in seeds $(V=6.3-11.3)$ and number of silicles per inflorescence $(V=20.7-43.2)$.

5. Thlaspi arvense responded most sensitively to meteorological conditions, its parameters and productivity were independent of the sowing time. The variation of phenological and productivity parameters such as the number of inflorescences and silicles under different weather conditions is indicative of high plasticity and adaptability of $T$. arvense.

6. Among the investigated species D. sophia exhibited the highest seed productivity of a single plant (in average $6.4 \pm 0.9 \mathrm{~g}$ ) and seed yield stability, while E. cheiranthoides distinguished itself by the highest (in average $37.8 \pm 2.6 \%$ (dry mass) and most stable $(V=6.9)$ seed oil content.

Received 19042013

Accepted 10042014

\section{References}

Aghaabasi K., Baghizadeh A. 2012. Investigation of genetic diversity in flixweed (Descurainia sophia) germplasm from Kerman province using inter-simple sequence repeat (ISSR) and random amplified polymorphic DNA (RAPD) molecular markers. African Journal of Biotechnology, 11 (43): 10056-10062

Byers D. L., Quinn J. A. 1998. Demographic variation in Alliaria petiolata (Brassicaceae) in four contrasting habitats. Journal of the Torrey Botanical Society, 125 (2): 138-149 http://dx.doi.org/10.2307/2997301

Carr M. E. 1985. Plant species evaluated for new crop potential. Economic Botany. 39 (3): 336-345 http://dx.doi.org/10.1007/BF02858804

Carr P. M. 1993. Potential of fanweed and other weeds as novel industrial oilseed crops. Janick J., Simon J. E. (eds). New crops, p. $384-388$

Cavers P. B., Heagy M. I., Kokron R. F. 1979. The biology of Canadian weeds. 35. Alliaria petiolata (M. Bieb.) Cavara and Grande. Canadian Journal of Plant Science, 59 (1): 217-229 http://dx.doi.org/10.4141/cjps79-029

Čekanavičius V., Murauskas G. 2002. Statistics and its applications, book II (in Lithuanian)

Dolya V., Shkurupii E., Podzolkova T., Kaminskii N. 1973. The seeds oil of some species of the family cruciferae. Khimiya Prirodnykh Soedinenii, 1: 15-18 (in Russian)

Downey R. K. 1971. Agricultural and genetic potentials of cruciferous oilseed crops. Journal of the American Oil Chemists Societv. 48 (11): 718-722 http://dx.doi.org/10.1007/BF02638528

Gandour M., Tamaalli W., Trabelsi N., Kamel H., Sebei K., Debez A., Abdelly C. 2012. How to optimize the seed and seed-oil production in the cash crop halophyte Cakile maritima? Journal of Medicinal Plants Research, 5 (25): $5982-5987$

Giontar E. M., Godin V. N. 2004. Morphological diversity and productivity of Erysimum cheiranthoides L. cultivated in Central Siberian botanical garden (Novosibirsk). Rastitelnye Resursy, 40 (2): 52-61 (in Russian)

Giontar E. M., Godin V. N. 2005. Effect of sowing density on the morphological characters of Erysimum cheiranthoides (Brassicaceae). Botanicheskij Zhurnal, 90 (2): 244-249 (in Russian)

Goffman F., Thies W., Velasco L. 1999. Chemotaxonomic value of tocopherols in Brassicaceae. Phytochemistry. 50: 793$798 \mathrm{http}: / /$ dx.doi.org/10.1016/S0031-9422(98)00641-4

Hume L. 1990. Influence of emergence date and strain on phenology, seed production, and germination of Thlaspi arvense L. Botanical Gazette, 151 (4): 510-515 http://dx.doi.org/10.1086/337851 
Jankevičienė R. 1971. Crucifers - brassicaceae. NatkevičaitėIvanauskienè M. (ed.). Flora of Lithuanian SSR, 3: 476514 (in Lithuanian)

Maršalkienė N., Sliesaravičius A., Karpavičienė B., Dastikaitė A 2009. Oil content and fatty acids composition of seeds of some Lithuanian wild crucifer species. Agronomy Research, 7 (2): 654-661

Miller R. W., Earle F. R., Wolff I. A. 1965. Search for new industrial oils. XIII. Oils from 102 species of cruciferae. Journal of the American Oil Chemists' Society, 4 (10): 817-821 http://dx.doi.org/10.1007/BF02541165

Meekins F., McCarthy B. 2000. Responses of the biennial forest herb Alliaria petiolata to variation in population density, nutrient addition and light availability. Journal of Ecology, 88 (3): $447-463$ http://dx.doi.org/10.1046/j.1365-2745.2000.00461.x

Moser B. R., Cermak S. C., Isbell T. A. 2008. Evaluation of castor and lesquerella oil derivatives as additives in biodiesel and ultralow sulfur diesel fuels. Energy Fuels, 22 (2): 1349-1352 http://dx.doi.org/10.1021/ef700628r

Moser B. R., Knothe G., Vaughn S. F., Isbell T. A. 2009 Production and evaluation of biodiesel from field pennycress (Thlaspi arvense L.) oil. Energy Fuels, 23 (8): 4149-4155 http://dx.doi.org/10.1021/ef900337g

Norton G., Harris J. F. 1983. Triacylglycerols in oilseed rape during seed development. Phytochemistry. 22 (12): 27032707 http://dx.doi.org/10.1016/S0031-9422(00)97676-3

Olšauskas A. M., Olšauskaitè-Urbonienè R. 2002. Protective dune of the Lithuanian seaside and elemental forces. Environmental Research, Engineering and Management, 2 (20): 18-25

Peng L., Yi Y., Fu Li G., Ze Qu L. 1997. A preliminary study on the introduction of Descurainia sophia, an oil plant species for industrial uses. Acta Botanica Sinica, 39 (5): 447-479
Piazza G., Foglia T. 2001. Rapeseed oil for oleochemical usage. European Journal of Lipid Science and Technology. 103 (7): 450-454 http://dx.doi.org/10.1002/14389312(200107)103:7<450::AID-EJLT450>3.0.CO;2-D

Raymer P. L. 2002. Canola: an emerging oilseed crop. Janwick J., Whipkey A. (eds). Trends in new crops and new uses, p. 122-126

Tavili A., Pouzesh H., Farajolahi A., Zare S., Zare C. M. A. 2010. The effect of different treatments on improving seed germination characteristics in medicinal species of Descurainia sophia and Plantago ovata. African Journal of Biotechnology, 9 (39): 6588-6593

Taylor D. C., Falk K. C., Palmer C. D., Hammerlindl J., Babic V., Mietkiewska E., Jadhav A., Marillia E. F., Francis T., Hoffman T., Giblin E. M., Katavic V., Keller W. A. 2010. Brassica carinata - a new molecular farming platform for delivering bio-industrial oil feedstocks: case studies of genetic modifications to improve very long-chain fatty acid and oil content in seeds. Biofuels Bioproducts and Biorefining. 4 (5): 538-561

http://dx.doi.org/10.1002/bbb.231

Warwick S. I., Francis A., Muligan G. A. 1999. Brassicaceae of Canada. Agriculture and Agri-Food. <http://res.agr.ca/ ecorc/cwmt/crucican $>$ [accessed 28012014 ]

Warwick S. I., Francis A., Susko D. J. 2002. The biology of Canadian weeds. 9. Thlaspi arvense L. Canadian Journal of Plant Science. 82 (4): 803-823 http://dx.doi.org/10.4141/P01-159

Zanetti F., Mosca G., Rampin E., Vamerali T. 2012. Adaptability and sustainable management of high-erucic Brassicaceae in Mediterranean environment. Akpan U. G. (ed.). Oilseeds, p. $99-116$

ISSN 1392-3196 / e-ISSN 2335-8947

Zemdirbyste-Agriculture, vol. 101, No. 2 (2014), p. 153-160

DOI 10.13080/z-a.2014.101.020

\title{
Kai kurių Lietuvos spontaninès floros bastutinių rūšių augalų agrobiologinis potencialas
}

\author{
N. Maršalkienè $\dot{1}^{1}$, A. Sliesaravičius ${ }^{1}$, A. Ramaškevičienè $\dot{1}^{1}$, L. Žilėnaité ${ }^{1}$, G. J. Švirmickas ${ }^{2}$ \\ ${ }^{1}$ Aleksandro Stulginskio universitetas \\ ${ }^{2}$ Lietuvos sveikatos mokslų universiteto Veterinarijos akademijos Gyvulininkystės institutas
}

\section{Santrauka}

Iš ịvairių Lietuvos rajonų surinktų penkių aliejingų bastutinių šeimos savaiminių rūšių augalu - paprastojo pokliaus (Descurainia sophia L.), smalkinio tvertiko (Erysimum cheiranthoides L.), dirvinės čiužutès (Thlaspi arvense L.), baltijinès stoklès (Cakile baltica Jord. ex Pobed.) ir vaistinės česnakūnès (Alliaria petiolata (M. Bieb.)) - 56 pavyzdžiu sèklos buvo pasètos rudenị (2008 bei $2009 \mathrm{~m}$.) ir pavasari (2009 bei $2010 \mathrm{~m}$.) Lietuvos žemès ūkio universiteto (dabar - Aleksandro Stulginskio universitetas) Bandymų stotyje, tarpinio (jürinio-kontinentinio) klimato sąlygomis karbonatingame sekliai glèjiškame išplautžemyje (IDg8-k). Visų tirtų rudeninės sèjos rūšiu augalai, išskyrus dirvinę čiužutę, išaugino aukštesnius stiebus ir pavasarinės sẻjos augalus lenkè produktyvumo rodikliais. Stabiliausi rodikliai buvo aliejaus kiekis sèklose $(V=6,3-11,3)$ ir ankštarų skaičius žiedyne $(V=20,7-$ $43,2)$, labiliausi - žiedynu skaičius $(V=30,93-94,4)$ ir vieno augalo sèklu derlius $(V=16,5-135,0)$. Dirvinè čiužute jautriausiai reagavo ị meteorologines sąlygas, jos stiebo aukštis ir produktyvumo rodikliai labiau priklause ne nuo sèjos laiko, bet nuo meteorologinių sąlygų vegetacijos metu. Paprastasis poklius pasižymèjo didžiausiu vieno augalo produktyvumu $(6,4 \pm 0,9 \mathrm{~g})$ ir požymių stabilumu. Smalkinis tvertikas iš tirtų rūšių pasižymèjo didžiausiu $(37,8 \pm 2,6 \%)$ ir stabiliausiu $(V=6,9)$ aliejaus kiekiu sèklose.

Reikšminiai žodžiai: aliejus, Alliaria petiolata, ankštaros, bastutiniai augalai, Cakile baltica, Descurainia sophia, Erysimum cheiranthoides, produktyvumas, sėklu derlius, Thlaspi arvense. 